\title{
Functional Food Formulation by the Addition of Whole Grain Flour and Linseed
}

\author{
Bakker, C.M.C.N. \\ Dep. Chemical Engineering (Federal University of Rio Grande do Norte- UFRN) \\ CEP 59072-970 Natal, Brazil \\ C. G. Pereira (Corresponding author) \\ Dep. Chemical Engineering (Federal University of Rio Grande do Norte- UFRN) \\ CEP 59072-970 Natal, Brazil \\ E-mail: camila@eq.ufrn.br
}

Received: October 9, 2017 Accepted: November 20, 2017 Published: December 8, 2017

doi:10.5296/jfi.v1i1.12274 URL: http://dx.doi.org/10.5296/jfi.v1i1.12274

\begin{abstract}
Recommendations for consuming industrialized whole grain foods have been encouraged. The present study produced new functional foods and sought to identify the sensory profile of the foods processed. Four types of dried spaghetti were manufactured with different formulas, regarding their whole grain flour and linseed content (10 and 20\%). For evaluation of the products obtained, the following methods were employed: sensory analysis of acceptance using a 9-point hedonic scale, applied to 50 trained judges, and Quantitative Descriptive Analysis (QDA) using a 9-cm unstructured line scale. Results were analyzed by ANOVA and Tukey's test at 5\% significance, and the sensory profile was expressed in the form of a spider graph. Acceptance test revealed no difference between the pasta containing $10 \%$ and $20 \%$ of whole grain and $10 \%$ of linseed. Results indicate acceptance of the $20 \%$ whole grain product regarding its raw texture and consistency when cooked, in addition to the possibility for the manufacture and acceptance of $10 \%$ linseed spaghetti.
\end{abstract}

Keywords: functional foods, enriched pasta, sensory analysis, quantitative descriptive analysis, whole grain flour

\section{Introduction}

The interest in functional foods has increased due to growing understanding of the public 


\section{MInstitute Macrothink $_{\text {Int }}$}

about the beneficial effects on health when of eating foods rich in bioactive compounds, e.g., omega 3 and omega 6 . However, not all processed foods contain originally such compounds.

In counterpoint to this awareness, dietary changes provoked by rapid urbanization in large cities include greater consumption of saturated fats and simple sugars, and less dietary fiber. This can trigger illnesses such as diabetes and heart disease resulting from poor eating habits (Silva \& Stamford, 2000). In the case of processed foods, a common technique in processing grains is the refining, which separates grain components and lowers their nutritional value. However, given the need to preserve nutrients in whole grain foods, in 2005 the World Health Organization determined, in its food guide for Brazil regarding grains, tubers and roots, that whole-grain versions of rice, wheat and corn-based foodstuffs should be prioritized (Brazil, 2005).

According to Brazilian Pasta Association (ABIMA), the national population currently consume more than 1.2 million tons of dried, fresh or instant pasta. Sales of food products containing fibers or those denominated as functional foods grew by $9.2 \%$ between January and September 2009. Regarding pastas, the industry is seeking to provide healthy, flavorful options for those who prioritize a healthy diet and, as such, are consistently researching new formulations.

Dietary fibers are a set of soluble non-starch polysaccharides, characterized by their resistance to hydrolysis by digestive enzymes in the intestinal tract. They can be divided into two fractions, according to the solubility of their components: a soluble fraction that ferments in the colon, generating products such as methane, hydrogen, carbon dioxide and short-chain fatty acids, which are metabolized. Physiological effects associated with this fraction are: lower blood cholesterol and control of glycolysis and, consequently, diabetes; the insoluble fraction, which is not fermented in the colon, is responsible for the beneficial effect of fibers in intestinal motility (Ordóñez, 2005).

With the presence of complex carbohydrates, foodstuffs made with whole grains are already being manufactured in Brazil. Their consumption is recommended by many dieticians and doctors, since they contain fibers derived from grain husks. Fibers promote a greater feeling of satiety and act in the gastrointestinal tract, serving as a substrate for microflora naturally present in the large intestine, whose maintenance is beneficial to health. Moreover, fibers modulate the speed of digestion and nutrient absorption, which is much slower than that of products made from refined grains. The use of whole grains helps to promote normal bowel movements, assisting in the prevention of diseases such as cancer, diabetes, diverticulosis, among others (ABIMA, 2010). According to Mattos and Martins (2000), foodstuffs can be classified in relation to the fiber content present in food, as follows: very high (more than $7 \mathrm{~g} / 100 \mathrm{~g}$ ); high (4.5 to $6.9 \mathrm{~g} / 100 \mathrm{~g}$ ); moderate $(2.4$ to $4.4 \mathrm{~g} / 100 \mathrm{~g}$ ) and low (less than $2.4 \mathrm{~g} / 100 \mathrm{~g})$.

As a complement of a healthy diet, linseed (Linum usitatissimum L.), seeds from the flax plant of the family Linaceae, also known as flaxseed, have been studied and used in functional foods. It contains on average $35 \%$ oil, $26 \%$ protein, $14 \%$ fiber, $12 \%$ mucilage and $9 \%$ moisture; its primary minerals are potassium, phosphorous, magnesium, calcium and 
sulfur (Moura, 2008). Flax seeds are used as a food supplement because they are rich in essential fatty acids and fibers. Added to bread, cakes and biscuits, or even mixed into food raw, they can be used as raw material in the production of oil, flour and bran.

Essential fatty acids are divided into two groups: the omega-3 family or linolenic acid, and the omega- 6 or linoleic acid, found in cold-water fish, vegetable oils, linseed, nuts and some vegetables (Jump, 2002). Linseed in its diverse forms has gained notoriety among functional foods (Mayes, 1994) as one of the largest recognized sources of omega 3 and omega 6 fatty acids, fibers and phenolic compounds, identified as antioxidants.

Studies on the role of oils and fats in human nutrition have emphasized the importance of consuming omega 3 fatty acids, reducing saturated fats and more recently, controlling consumption of trans fatty acids (Ascherio, 1999).

In 1999, Food and Drugs Administration - FDA (2006) recommended that trans-fat content be included on food labels. In December 2003, ANVISA (National Health Surveillance Agency) in Brazil published resolution $\mathrm{n}^{\mathrm{0}} 360$, a technical regulation on nutrition labeling of packaged foods, making trans-fat content a mandatory item.

In 2000, Food and Agriculture Organization of the United Nations - FAO recommended a daily consumption ratio of omega- 6 - omega-3 fatty acids between 5:1 and 10:1, respectively. Some organizations find it more efficient to establish adequate consumption levels of fatty acids individually than determine the ratio between them. As such, developing foods containing linseed contributes to consumption of this seed as a functional food (Cunnane et al. 1995; Hall et al. 2005).

Studies on the manufacture of enriched pastas have increased in recent years (Ataiza et al 2010, Pagnussatt et al. 2014, Ak et al. 2016). However, very little has been studied about this subject, many in the sensorial terms. In this scenario, the present study aimed to describe the profile of sensory attributes of dried spaghetti with the addition of enriched flour and evaluate acceptance through sensory analysis. To that end, standard formulations were used with the addition of $10 \%$ and $20 \%$ whole grain flour and flour containing an additional $10 \%$ and $20 \%$ of linseed, obtaining pasta through high-temperature drying.

Sensory food quality is directly related to consumer choice based on tasting, where the product must stimulate the senses to be accepted in the market and eventually become a regular component of diet. It has been suggested that human sense organs be used as measuring "instruments" in order to guarantee food quality (Della Torre et al., 2003). Thus, sensory analysis becomes necessary as an acceptance criterion when developing a product and is a useful tool in research concerning viable products.

\section{Material and Methods}

\subsection{Raw Material}

Standard and whole grain flour were obtained in April and June 2010 from the Grande Moinho Potiguar production unit in Natal, Brazil, milled from Triticum aestevum flour containing $5.6 \mathrm{mg}$ of iron and $210 \mathrm{mcg}$ pholic acid, in accordance with current legislation 


\section{Ml Macrothink}

(Brazil, 2002). Brown flaxseed meal (lot $\left.\mathrm{n}^{\circ} 23056\right)$ from Canada was acquired from Cerealista Superior LTDA (Recife, Brazil).

Flour was formulated in accordance with the following compositions: F1) 90\% wheat flour and 10\% whole grain flour; F2) $80 \%$ wheat flour and 20\% whole grain flour; F3) $90 \%$ wheat flour and 10\% linseed meal; and F4) $80 \%$ wheat flour and $20 \%$ linseed meal.

Flour and pasta samples were collected at Grande Moinho Potiguar Natal, Brazil, according to standard procedure. Product characteristics were allowed to stabilize, and a minimum of 20 $\mathrm{kg}$ of product was used for sensory analysis.

In comparative analysis, Excelsa brand dried whole grain spaghetti was used, containing only whole grain flour without improver ingredients. Spaghetti with added linseed meal was not found in the local market.

\subsection{Recruitment and Testing conditions}

The sensory team was composed of 50 judges, employees of a manufacturing plant aged between 18 and 45 years. Training began with theoretical and practical instruction on sensory analysis of dried spaghetti. Clarifications were given regarding volunteering, responsibilities of tests and allergens (test products containing gluten). This was followed by a basic taste test and presentation of the characteristics of the different types of spaghetti (color, odor, flavor and texture), their flaws and it was defined which tests would be conducted, in order to foster commitment and awareness for the activity in question. Terminology concepts related to sensory properties were also addressed, in accordance with ABNT norms (1993). The same preparation method was used for all pastas, which were cooked in a proportion of $100 \mathrm{~g}$ of pasta for every liter of water, with $5 \mathrm{~g}$ of table salt. Cooking time followed instructions on the packaging and the pasta was served at recommended temperatures of around 35 to $45^{\circ} \mathrm{C}$ (IAL, 2005). All containers used were clean, dry and odor-free. Pasta samples were served in individual tasting booths in a quiet, well-lit, odor-free air-conditioned environment.

For products containing linseed, appropriate cooking times were assessed according to the food items by compressing a spaghetti strand between two glass plates. Evaluation occurred every 10 seconds to determine the moment of complete gelation, that is, when color was uniform without white areas indicating raw pasta, enabling it to be served for sensory analysis (ITAL, 1986).

\subsection{Sensory Analyses}

\subsubsection{Acceptance Test}

In order to measure the extent of acceptance of pasta produced with added whole grain flour and linseed meal, a subjective or affective method was applied using a 9-point hedonic scale (1, extreme disapproval to 9, extreme approval). Samples coded with three digits were presented to judges whose preference was obtained by inference. Data were statistically assessed by analysis of variance (ANOVA) and means of paired samples were compared using Tukey's test (IAL, 2005). 


\subsubsection{ADQ}

The ADQ was developed using a descriptive quantitative normative design, in accordance with the NBR 14140 norm (ABNT, 1998) and descriptive terminology of the products. It was depicted in spider graph format, identifying similarities and differences between samples. In this type of graph, the center represents zero on the attribute scale and intensity increases from the center to the edge. The mean of each attribute was marked on the corresponding axis and the sensory profile was drawn by connecting the points (Ormenese, 2001).

\subsubsection{Developing Descriptive Terminology}

Descriptive terminology was devised using the Network Method. In individual tasting booths, products were presented in pairs to pre-selected tasters. Individuals were asked to describe on a form the similarities and differences between each pair of samples in regard to appearance, aroma, flavor and texture. Following tasting sessions, the judges discussed the terms used in order to eliminate redundancies or those least cited. Terminology that best described the differences and similarities between food items was selected by consensus.

Definitions for each descriptive term were developed by the sensory team and are displayed in Table 1. Reference materials and descriptive definitions were made available to tasters in each session. Training was terminated when tasters demonstrated no difficulty evaluating samples using the Assessment Form.

Table 1. Definition of descriptive terms and reference materials for pasta.

\begin{tabular}{|c|c|c|}
\hline \multicolumn{3}{|l|}{ ASPECT } \\
\hline Descriptors & Definition & References \\
\hline Coloring & $\begin{array}{l}\text { Color tone ranging from cream } \\
\text { to brown with dark spots, in } \\
\text { pasta assessment. }\end{array}$ & $\begin{array}{l}\text { Light: rice noodles. } \\
\text { Dark: whole grain pasta with added linseed. }\end{array}$ \\
\hline Texture & $\begin{array}{l}\text { Tactile and visual sensation } \\
\text { perceived by judge when } \\
\text { handling the raw pasta. }\end{array}$ & $\begin{array}{l}\text { Bad: raw pasta with flaws (white spots, cracks, rough, } \\
\text { brittle and ripples). } \\
\text { Excellent: raw pasta with no flaws (uniform and } \\
\text { smooth). }\end{array}$ \\
\hline Consistency & $\begin{array}{l}\text { Resistance to chewing with the } \\
\text { front teeth and tactile evaluation } \\
\text { of the viscosity of cooked pasta. }\end{array}$ & $\begin{array}{l}\text { Viscous: viscous (sticky) and disintegrating cooked } \\
\text { pasta. } \\
\text { Al dente: cooked pasta which, when chewing with the } \\
\text { front teeth, feels soft at first and then resistant. } \\
\text { Hard: cooked pasta very resistant to chewing with total } \\
\text { lack of viscosity. }\end{array}$ \\
\hline \multicolumn{3}{|c|}{ FLAVOR AND ODOR } \\
\hline Wheat flavor & $\begin{array}{l}\text { Joint sensory perception of } \\
\text { flavor and odor of cooked pasta } \\
\text { made from wheat components. }\end{array}$ & $\begin{array}{l}\text { Low: cooked rice noodles. } \\
\text { Intermediate: cooked durum wheat pasta. } \\
\text { High: cooked whole grain pasta. }\end{array}$ \\
\hline Linseed flavor & $\begin{array}{l}\text { Joint sensory perception of } \\
\text { linseed flavor and odor. }\end{array}$ & $\begin{array}{l}\text { Low: cooked rice noodles. } \\
\text { High: linseed flavor. }\end{array}$ \\
\hline
\end{tabular}




\subsection{Sample Assessment}

The sensory profile of four pasta samples was evaluated by nine trained tasters under conditions ensuring the individuality of judges, with monadic presentation of food items in different orders. The intensity of each descriptor was assessed for every sample using a 9-cm unstructured line scale, with terms of intensity anchored at its ends; minimum on the left and maximum on the right.

\subsection{Statistical Analyses}

Results of QDA were submitted to Analysis of Variance (ANOVA) of samples and Tukey's test at 5\% significance. Excel 2007 spreadsheets were used to compare means and compile the spider graph depicting descriptors chosen by the group of judges.

\section{Results and Discussion}

\subsection{Acceptance Test with a 9-Point Hedonic Scale Performed by 50 Trained Judges}

In this work, new functional products were prepared by adding whole grain flour and linseed in the spaghetti. Table 2 summarizes acceptance test results for samples of pasta with added whole grain flour and linseed, as well as comparison with a commercial whole grain sample. In this test, sensory attributes of flavor, odor, texture and color are considered together to determine the acceptance score.

Table 2. Summary of sensory analysis of enriched spaghetti from 50 trained judges using a 9-point hedonic scale*.

\begin{tabular}{|c|c|c|c|c|c|}
\hline \multirow[b]{2}{*}{ Result } & \multicolumn{5}{|l|}{ Samples } \\
\hline & $\begin{array}{l}10 \% \text { whole } \\
\text { grain }\end{array}$ & $\begin{array}{l}20 \% \text { whole } \\
\text { grain }\end{array}$ & 10\%linseed & 20\%linseed & $\begin{array}{l}\text { Commercial } \\
\text { whole grain }\end{array}$ \\
\hline Mean & $6.7^{\mathrm{a}}$ & $6.0^{\mathrm{ab}}$ & $5.5^{\mathrm{b}}$ & $4.9^{c}$ & $1.9^{\mathrm{c}}$ \\
\hline Acceptance rate $-\mathrm{AR} \%$ & 74 & 75 & 61 & 54 & 63 \\
\hline
\end{tabular}

*Means accompanied by the same letter in the same line do not differ significantly amongst themselves $(\mathrm{p}<0.05)$.

Results of mean assessments indicate good acceptance for pastas with additional whole grain flour, obtaining values between 6 (20\% whole grain) and 7 (10\% whole grain), equivalent to "slight approval" and "moderate approval", respectively. However, for items containing linseed meal, values fell to 5 (20\% linseed) and 6 (10\% linseed), corresponding to "indifference" and "slight approval". Commercial whole grain pasta (without additives), available in the local market, exhibited a mean of 2, reflecting "extreme disapproval".

Evaluation according to acceptance rate - AR (Teixeira et al., 1987) reveals that $10 \%$ and $20 \%$ whole grain spaghettis achieved complete sensory acceptance, with AR higher than $70 \%$. The remaining spaghetti samples were considered unacceptable, since they obtained AR values of $63 \%$ (commercial whole grain pasta), 61\% (10\% linseed pasta) and 54\% (20\% linseed pasta). 


\section{Ml Macrothink}

3.2 ANOVA Assessment of the 9-Point Hedonic Scale Acceptance Test Carried out by 50 Trained Judges

Table 3 shows the results of ANOVA calculations, considering the sample, judges and residue as factors of variation. The value of $\mathrm{F}_{\text {calculated }}=57.92$ was higher than $\mathrm{F}_{\text {tabulated }}=2.37$, confirming a significant difference between at least two or more of the samples according to the perception of tasters, with significance of 5\%. Comparison between means needs to be examined. Table 4 exhibits the result corresponding to the difference between mean values related to the judging of each sample in all possible comparisons.

Table 3. ANOVA calculation*.

\begin{tabular}{llllll}
\hline Sources of variation & GL & SQ & QM & F calculated & F $_{\text {tabulated }}$ \\
\hline Sample & 4 & 694.26 & 173.56 & 57.92 & $2.37^{* *}$ \\
\hline Judge & 49 & 244.34 & 4.99 & - & \\
\hline Residue & 196 & 587.34 & 3.00 & - & - \\
\hline Total & 249 & 1525.94 & - & & - \\
\hline
\end{tabular}

*Significant difference of 5\%.**Second annex G tab. 35 (Dutcosky, 2007).

Table 4. Calculation of significant difference between mean values for decisions regarding each sample in possible comparisons for different samples of spaghetti

\begin{tabular}{ll}
\hline Samples & Differences between sample means \\
\hline $10 \%$ whole grain - $20 \%$ whole grain & 0.74 \\
\hline $10 \%$ whole grain - $10 \%$ linseed & $1.24^{*}$ \\
\hline $10 \%$ whole grain - $20 \%$ linseed & $1.76^{*}$ \\
\hline $10 \%$ whole grain - commercial whole grain & $4.84^{*}$ \\
\hline $20 \%$ whole grain - $10 \%$ linseed & 0.50 \\
\hline $20 \%$ whole grain - $20 \%$ linseed & $1.02^{*}$ \\
\hline $20 \%$ whole grain - commercial whole grain & $4.10^{*}$ \\
\hline $10 \%$ linseed - 20\% linseed & 0.52 \\
\hline $10 \%$ linseed - commercial whole grain & $3.60^{*}$ \\
\hline $20 \%$ linseed- commercial whole grain & $3.00^{*}$ \\
\hline
\end{tabular}

*Occurrence of significance due to means higher than MSD $=0.89$.

Table 4 demonstrates no significant difference in joint assessment for the attributes flavor, odor, texture, and color between $10 \%$ and $20 \%$ whole grain; $20 \%$ whole grain and $10 \%$ linseed; as well as between $10 \%$ linseed and $20 \%$ linseed, for the 50 trained judges. A significant difference of $5 \%$ was recorded between the commercial whole grain pasta and the remaining products (10\% whole grain, $20 \%$ whole grain, $10 \%$ linseed, $20 \%$ linseed). 


\section{Macrothink}

\subsection{QDA Analysis}

Figure 1 depicts the coloring of the 10\% whole grain, $20 \%$ whole grain, commercial whole grain, $10 \%$ linseed and $20 \%$ linseed samples, when judging the coloring of raw pasta in QDA.

Figure 1 indicates (from left to right) gradual darkening of pasta to brown tones. The small light brown spots characteristic of wheat bran also gradually increased with the addition of whole grain flour (10\% and $20 \%$ whole grain). The two last samples, linseed pastas, exhibited a gradual increase in brown coloring characteristic of linseed meal. Table 5 displays the result of QDA sensory testing, using the 9-cm unstructured scale, described and reported by 9 judges, selected and trained regarding the intensity of attributes selected for the products.

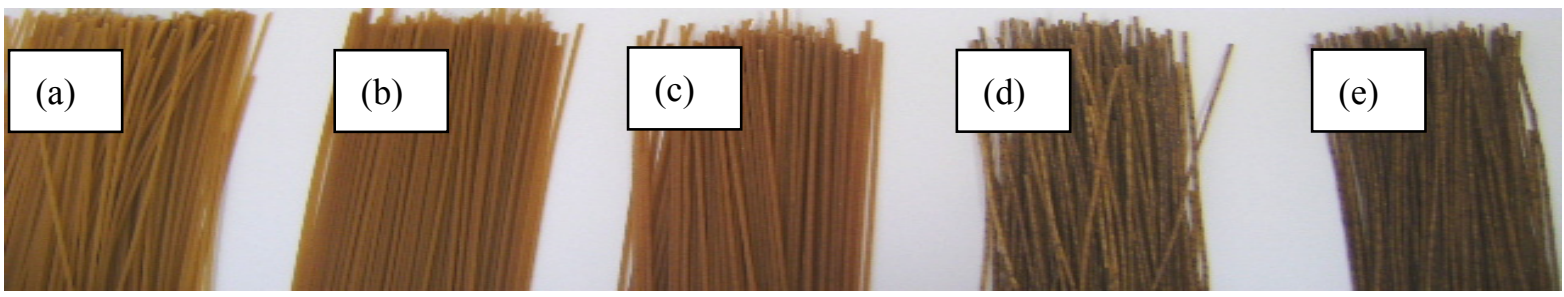

Figure 1. Colouring of raw pasta with different formulations (a) 10\% whole grain spaghetti, (b) $20 \%$ whole grain spaghetti, (c) commercial whole grain spaghetti, (d) $10 \%$ linseed spaghetti and (d) 20\% linseed spaghetti)

Table 5. Result of decision means in the QDA sensory testing phase with 9 trained judges.

\begin{tabular}{|c|c|c|c|c|c|c|}
\hline \multirow{2}{*}{$\begin{array}{l}\text { Sensory } \\
\text { attribute }\end{array}$} & \multicolumn{5}{|l|}{ Samples } & \multirow[b]{2}{*}{ MSD } \\
\hline & $\begin{array}{l}10 \% \text { Whole } \\
\text { grain }\end{array}$ & $\begin{array}{l}\text { 20\%Whole } \\
\text { grain }\end{array}$ & $\begin{array}{l}\text { Commercial whole } \\
\text { grain }\end{array}$ & 10\%Linseed & 20\%Linseed & \\
\hline Wheat flavor & $3.78^{\mathrm{a}}$ & $5.79^{\mathrm{a}}$ & $3.79^{\mathrm{a}}$ & $8.40^{\mathrm{b}}$ & $4.80^{\mathrm{a}}$ & 3.29 \\
\hline Linseed flavor & - & - & - & $6.18^{\mathrm{a}}$ & $8.06^{\mathrm{b}}$ & 0.95 \\
\hline $\begin{array}{l}\text { Cooked } \\
\text { consistency }\end{array}$ & $4.38^{\mathrm{a}}$ & $4.54^{\mathrm{a}}$ & $3.06^{\mathrm{a}}$ & $2.98^{\mathrm{a}}$ & $3.02^{\mathrm{a}}$ & 1.83 \\
\hline Raw texture & $6.06^{\mathrm{a}}$ & $5.39^{\mathrm{a}}$ & $3.77^{\mathrm{a}}$ & $3.98^{\mathrm{a}}$ & $4.20^{\mathrm{a}}$ & 3.15 \\
\hline Raw coloring & $4.83^{\mathrm{a}}$ & $4.99^{\mathrm{a}}$ & $4.24^{\mathrm{a}}$ & $5.68^{\mathrm{ab}}$ & $8.04^{\mathrm{b}}$ & 2.37 \\
\hline $\begin{array}{l}\text { Cooked } \\
\text { coloring }\end{array}$ & $4.06^{\mathrm{a}}$ & $4.03^{\mathrm{a}}$ & $3.13^{\mathrm{a}}$ & $4.59^{\mathrm{a}}$ & $6.57^{\mathrm{b}}$ & 2.07 \\
\hline
\end{tabular}

*Means accompanied by the same letter in the same line are not significantly different amongst themselves, with a 5\% significance level per attribute. (-) item not required.

As shown in Figure 1 regarding the coloring attribute for raw pasta, color became less intense for all products after cooking. The outcome of sensory tests is represented graphically in 


\section{Macrothink

Figure 2, showing the intensity of attributes perceived in the 5 samples (10\% whole grain, $20 \%$ whole grain, $10 \%$ linseed, $20 \%$ linseed and commercial whole grain).

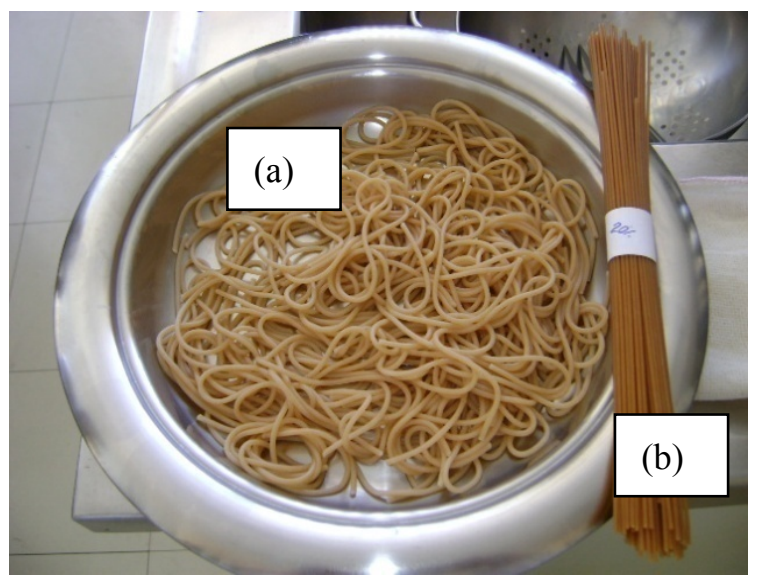

Figure 2. Colouring of the $20 \%$ whole grain pasta cooked (a) and dried (b)

In accordance with QDA data in Figure 3, the $10 \%$ and $20 \%$ whole grain pastas achieved similar profiles for the attributes raw texture and cooked consistency, diverging from the $10 \%$ and $20 \%$ linseed and commercial whole grain samples, which displayed similar, lower profiles. As such, QDA analysis confirms the similarity of $10 \%$ and $20 \%$ whole grain samples and inferior profile of the commercial whole grain sample, in all attributes. Perception of the judges was notable for linseed pastas, with an increased sensory profile for the attributes of raw coloring, cooked coloring and wheat flavor. However, a decline was recorded in the sensory profile for raw texture and cooked consistency.

These results show that $10 \%$ linseed spaghetti produced greater perceived wheat flavor. On the other hand, the $20 \%$ linseed product receives higher scores in the other attributes, which visibly represents increased intensity for a product that appeals to health, since the target public is diverse (avid consumers of whole grain food). 


\section{Macrothink}

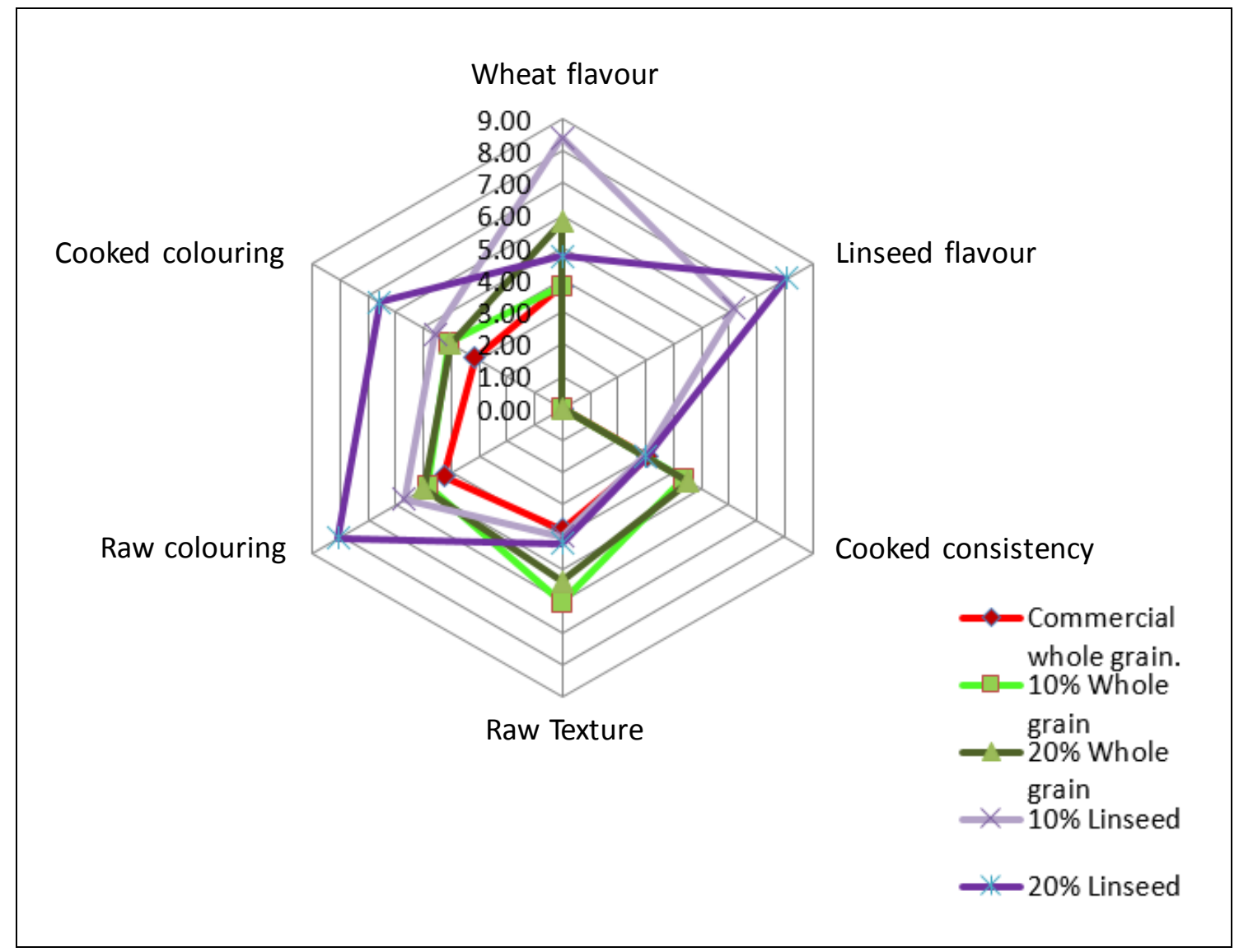

Figure 3. Spider graph representing QDA means for enriched spaghetti samples.

From this study, it was observed that the linseed-enriched product tested becomes a viable alternative for the inclusion of essential fatty acids in daily diets. Although the $10 \%$ linseed sample was not considered different in relation to whole grain items produced, it did not achieve a high enough acceptance percentage to justify its production. This emphasizes the importance of research to define a sensory profile for the new product, as yet not described in the literature. Thus, when developing a product, it is important to consider its nutritional value and target market in advertising campaigns, since this would add value to the product and make its production viable even with low commercialization.

\section{Conclusion}

In this work, studies concerning new functional products prepared by adding whole grain flour and linseed in the spaghetti were carried out. The acceptance test conducted with 50 tasters trained in evaluation using a 9-point hedonic scale identified no difference between $10 \%$ whole grain, $20 \%$ whole grain and $10 \%$ linseed. Of these, $20 \%$ linseed exhibited the lowest test mean, and the Excelsa brand whole grain pasta obtained the lowest mean among all products. Items that achieved an acceptance rate greater than $70 \%$ were the $10 \%$ and $20 \%$ whole grain pastas, suggesting the possibility of commercial production.

In QDA representation of the 9-cm unstructured scale, whole grain products did not differ 
significantly in any attribute. The pasta containing $10 \%$ additional linseed was considered significantly different in relation to more intense wheat flavor. The commercial whole grain pasta displayed lower values in the QDA profile for all attributes. The $10 \%$ and $20 \%$ whole grain samples had the best raw texture and cooked consistency among the other products. All samples obtained lower values in the coloring aspect in sensory comparison between raw and cooked forms.

This study provided an important evaluation about the acceptance of a new functional products prepared by adding whole grain flour and linseed. The results demonstrated the approval of the products, being it relevant for the development of new functional foods providing new possibilities of foods rich in nutrients that contribute to human metabolism.

\section{Acknowledgments}

The authors are grateful to Dias Branco industry for technical support.

\section{References}

ABIMA, Associação Brasileira de Massas Alimentícias (2010). História, aspectos nutricionais, tipos e formatos de massas. Retrieved December 5, 2017, from http://www.abima.com.br

ABNT - Associação Brasileira de Normas Técnicas (Brazilian Association of Technical Standards) (1993). NBR 12806: Análise sensorial dos alimentos e bebidas. Rio de Janeiro. Retrieved December 5, 2017, from http:// www.abnt.org.br

ABNT - Associação Brasileira de Normas Técnicas (Brazilian Association of Technical Standards) (1998). NBR 14140: Alimentos e bebidas - teste de análise descritiva quantitativa $(A D Q)$. Rio de Janeiro. Retrieved December 5, 2017, from http:// www.abnt.org.br

Ak B., Avşaroglu, E., Isık O., Ozyurt, G., Kafkas, E., Etyemez, M., \& Uslu, L. (2016). Nutritional and Physicochemical Characteristics of Bread Enriched with Microalgae Spirulina platensis. International Journal of Engineering Research and Application, 6, 30-38. Retrieved December 5, 2017, from http:/ www.ijera.com

Ascheiro, A. (1999). Trans fatty acids and coronary heart disease. New England Journal of Medicine. 340, 25, 1994. https://doi.org/10.1136/bmj.333.7561.214

Ataíza, M., Ruiz, L., \& Elizalde, A. (2010). Production of Food Pastas Enriched from Quinua's (Chenopodium quinoa wild.) flour and Carrot (Dacus carota). Biotecnología en el Sector Agropecuario y Agroindustrial. 8(1), 43-53. Retrieved December 5, 2017, from http://www.scielo.org.co/scielo.php?script=sci_arttext\&pid=S1692-35612010000100006\&ln $\mathrm{g}=\mathrm{en} \& \mathrm{nrm}=\mathrm{iso}>$

BRASIL, Agência Nacional de Vigilância Sanitária- ANVS (2005). Technical Regulation for cereal products, starch, flour and bran. RDC No 263- 22/09/2005 - MS. Retrieved December 5, 2017, from http://portal.anvisa.com.br

BRASIL, Agência Nacional de Vigilância Sanitária- ANVS (2002). Technical Regulation for 


\section{MInstitute ${ }^{\text {Macrothink }}$}

the fortification of flour of wheat and flour corn with Iron and Folic Acid. RDC n $n^{\circ}$ 344/02 18/12/2002 - MS. http://portal.anvisa.com.br. (December 5, 2017).

Cunnane, S. C. (1995). Nutritional Attributes of traditional flaxseed in healthy young adults. American Journal of Clinical Nutrition, 61, 1, 62-68. Retrieved December 5, 2017, from http://ajcn.nutrition.org/content/61/1.toc (December 5, 2017).

Della Torre, J. C. M., Rodas, M. A. B., Bodalato, G. G., \& Tadini, C. C. (2003). Sensory evaluation and consumer test of minimally processed orange juice. Food Science and Technology, 23, 2, 105-111. https://doi.org/10.1590/S0101-20612003000200001

Dutcosky, S. D. (2007). Análise sensorial de alimentos. Curitiba: Champagnat, 223.

FDA - Food and Drug Administration, (2003). Proposes new rules for trans fatty acids in nutrition labeling, nutrient content clains, snd health clains. Retrieved December 5, 2017, from http://www.gpoaccess.gov/index.html

Hall III, C. A. (2005). Stability of a-Linolenic Acid and Secoisolariciresinol Diglucoside in Flaxseed-Fortified Macarroni. Journal of Food Science, 70, 483-489. https://doi.org/10.1111/j.1365-2621.2005.tb11505.x

IAL, Instituto Adolfo Lutz (2005). Métodos físicos-químicos para análise de alimentos, Normas Analíticas do Instituto Adolfo Lutz.14. Ed. Brasília. Retrieved December 5, 2017, from http:// www.ial.sp.gov.br

Jump, D. B. (2002). The biochemistry of n-3 polyunsatureyed fatty acids. Journal of Biological Chemistry, 277, 8755-8758. https://doi.org/10.1074/jbc.R100062200

Mattos, L. L. \& Martins, I. S. (2000). Dietary fiber consumption in an adult population. Public Health Journal, 34, 50-55. http://dx.doi.org//10.1590/S0034-89102000000100010.

Mayles, P. A. (1994). Lipídios de Importância Fisiológica. In: Harper: Bioquímica. $7^{\mathrm{a}}$ Ed. São Paulo: Atheneu. 142.

Moura, N. C. (2008). Características físico-químicas, nutricionais e sensoriais de pão de forma com adição de grãos de linhaça (Linum usitatissimum). (Master's Thesis). Escola Superior de Agricultura Luiz de Queiroz. University of São Paulo, Piracicaba, Brazil.

Ormenese, R. C. S. C. Rodriguez, M. I. C.; Alvarez, L. F., Sanz, M. L. G., Minguillón, G.. G. F., Perales, L. H., \& Cortecero, M. D. S. (1998). Influence on high temperature drying on Egg Pasta Characteristics. Food Science and Technology. 18, 7-12. https://doi.org/10.1590/S0101-20611998000100003

Ordonez, J. A. P., Rodriguez, M. I. C., Alvarez, L. F., Sanz, M. L. G., Minguillón, G. G. F., Perales, L. H., \& Cortecero, M. D. S. (2005). Tecnologia de alimentos, Alimentos de origem animal. Ed. Sintesis. 2, 294.

Pagnussatt, F. A., Spier, F., Bertolin, T. E., Costa, J. A. V., \& Gutkoski, L. C. (2014). Technological and nutritional assessment of dry pasta with oatmeal and the microalga Spirulina platensis. Brazilian Journal of Food Technology, 17, 296-304. 


\section{Macrothink}

Journal of Food Industry

ISSN 1948-545X 2017, Vol. 1, No. 1

https://doi.org/10.1590/1981-6723.1414

Silva, L. L., \& Stamford, T. L. M. (2000). Alimentos prebióticos: uma revisão. Higiene Alimentar, 14, 41-50. http://higienealimentar.com.br

Teixeira, E., Meinert, E. \& Barbetta, P. (1987). Análise sensorial de alimentos. Série Didática. Florianópolis: Ed. USFC, 102.

\section{Copyright Disclaimer}

Copyright for this article is retained by the author(s), with first publication rights granted to the journal.

This is an open-access article distributed under the terms and conditions of the Creative Commons Attribution license (http://creativecommons.org/licenses/by/3.0/). 